\title{
Erratum to: Principal Component and Multiple Regression Analysis for Steel Fiber Reinforced Concrete (SFRC) Beams
}

\author{
Mohammad S. Islam ${ }^{1,2), *}$, and Shahria Alam ${ }^{1)}$
}

Published online: March 19, 2014

\section{Erratum to: International Journal of Concrete Structures and Materials (2013) 7(4):303-317 DOI 10.1007/s40069-013-0059-7}

The following incorrect text in the abstract "(low strength with $f_{c}^{\prime}<50 \mathrm{MPa}$ and high strength with $f_{c}^{\prime}<50 \mathrm{MPa}$ )" should be replaced with "(low strength with $f_{c}^{\prime}<50 \mathrm{MPa}$ and high strength with $\left.f_{c}^{\prime} \geq 50 \mathrm{MPa}\right)$.

\section{Open Access}

This article is distributed under the terms of the Creative Commons Attribution License which permits any use, distribution, and reproduction in any medium, provided the original author(s) and the source are credited.

\footnotetext{
The online version of the original article can be found under doi:10.1007/s40069-013-0059-7.

${ }^{1)}$ School of Engineering, The University of British Columbia, Okanagan Campus, Kelowna, BC V1V 1V7, Canada.

${ }^{2)}$ Department of Statistics, McMaster University, Hamilton, ON L8S 4L8, Canada.

*Corresponding Author;

E-mail: mohammis@mcmaster.ca

Copyright ( $\odot$ The Author(s) 2014. This article is published

with open access at Springerlink.com
} 